\title{
Morphometric analysis of various measurements of malleus on the basis of sexual dimorphism
}

\author{
Mayankkumar Javia ${ }^{1, *}$, P. Saravanan ${ }^{2}$ \\ ${ }^{\mathbf{1}}$ Associate Professor, ${ }^{\mathbf{2}}$ Assistant Professor, Dept. of Anatomy, ${ }^{\mathbf{1} B a n a s}$ Medical College and Research Institute, Palanpur, Gujarat, ${ }^{\mathbf{2} G u j a r a t}$ \\ Adani Institute of Medical Sciences, Bhuj, Gujarat, India \\ *Corresponding Author: Mayankkumar Javia \\ Email: drjaviamd@gmail.com
}

\begin{abstract}
The malleus is the largest of the ear ossicles. In the present study, we tried to determine the normal range of the values of various measurements of malleus and whether these measurements are useful for the sexual dimorphism or not. Out of total 60 malleus used in the present study, 30 were retrieved from the male cadavers and 30 were retrieved from the female cadavers. Mean of total length of malleus, mean of length of manubrium of malleus and mean of length of head and neck of malleus in male are more as compared to female in the present study. Mean of index of malleus in male is less as compared to female in the present study. Among all the measurements taken in the present study; total length of malleus having statistically significant difference between the male and female malleus and it can be used for the sexual dimorphism of malleus for Kachchhi Gujarati population of present study.
\end{abstract}

Keywords: Total length of malleus, Length of manubrium of malleus, Length of head and neck of malleus, Index of malleus.

\section{Introduction}

The malleus is the largest of the ossicles, and is shaped somewhat like a mallet. It is 8-9 $\mathrm{mm}$ long and has a head, neck, handle (manubrium) and anterior and lateral processes. The head is the large upper end of the bone and is situated in the epitympanic recess. It is ovoid in shape, articulates posteriorly with the incus, and is covered elsewhere by mucosa. The cartilaginous articular facet for the incus is narrowed near its middle and consists of a larger upper part and a smaller lower part, orientated almost at right angles to each other. Opposite the constriction, the lower margin of the facet projects in the form of a process, the spur of the malleus. The neck is the narrowed part below the head, and inferior to this is an enlargement from which the anterior and lateral processes project. The handle of the malleus is connected by its lateral margin to the tympanic membrane. It is directed downwards, medially and backwards. It decreases in size towards its free end, which is curved slightly forwards and is flattened transversely. Near the upper end of its medial surface there is a slight projection to which the tendon of tensor tympani is attached. The anterior process is a delicate bony spicule, directed forwards from the enlargement below the neck, and connected to the petrotympanic fissure by ligamentous fibres. In fetal life it is the longest process of the malleus and is continuous in front with Meckel's cartilage. The lateral process is a conical projection from the root of the handle of the malleus. It is directed laterally and is attached to the upper part of the tympanic membrane and, via the anterior and posterior malleolar folds, to the sides of the notch in the upper part of the tympanic sulcus. The cartilaginous precursor of the malleus originates as part of the dorsal end of Meckel's cartilage. With the exception of its anterior process, the malleus ossifies from a single endochondral centre which appears near the future neck of the bone in the fourth month in utero. The anterior process ossifies separately in dense connective tissue and joins the rest of the bone at about the sixth month of fetal life.

In the present study, we tried to determine the normal range of the values of various measurements of malleus and whether these measurements are useful for the sexual dimorphism or not.

\section{Materials and Methods}

In the present study, 60 dry adult malleus bones were used. These bones were retrieved during the routine dissection of cadavers donated to the Department of Anatomy, Gujarat Adani Institute of Medical Sciences, Bhuj, Gujarat, India. Out of total 60 malleus used, 30 were retrieved from the male cadavers and 30 were retrieved from the female cadavers. Pathological, fractured or malleus of unknown sex were excluded from the study. Only fully ossified malleus of known sex were included in the study. The study was done during the year 2017-18 after the prior approval of the institutional ethics committee of Gujarat Adani Institute of Medical Sciences, Bhuj, Gujarat, India.

Following measurements of the malleus were taken by using digital vernier caliper:

1. Total length of malleus [Fig. 1]

Total length of malleus was measured as the maximum straight distance between the top of the head and the end of the manubrium of the malleus. 


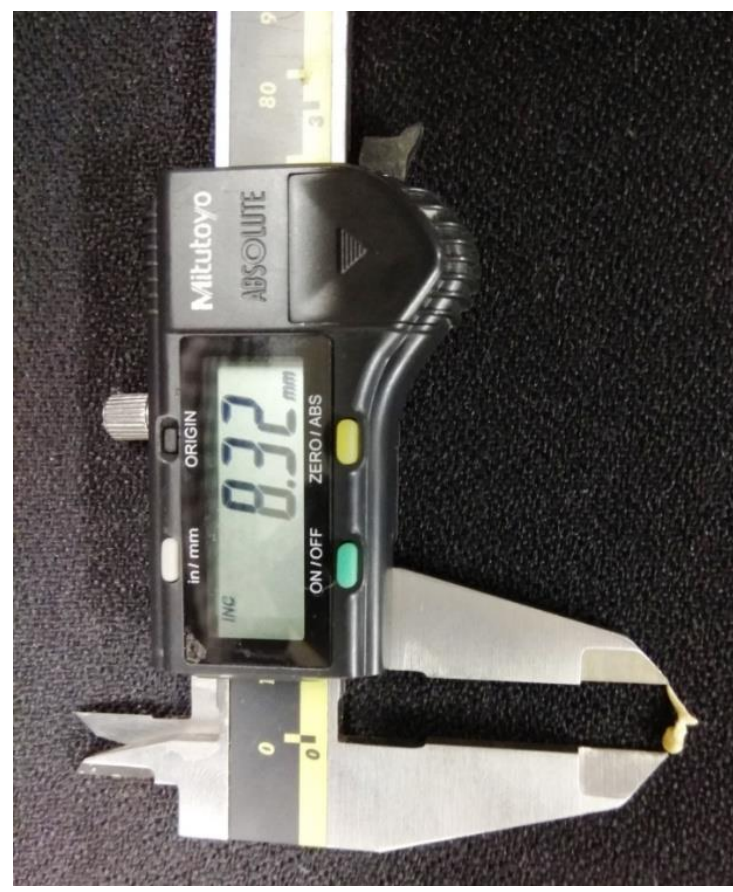

Fig. 1: Showing the measurement of total length of malleus

\section{Length of manubrium of malleus [Fig. 2]}

Length of manubrium of malleus was measured as the maximum straight distance between the end of the lateral process and the end of the manubrium of the malleus.

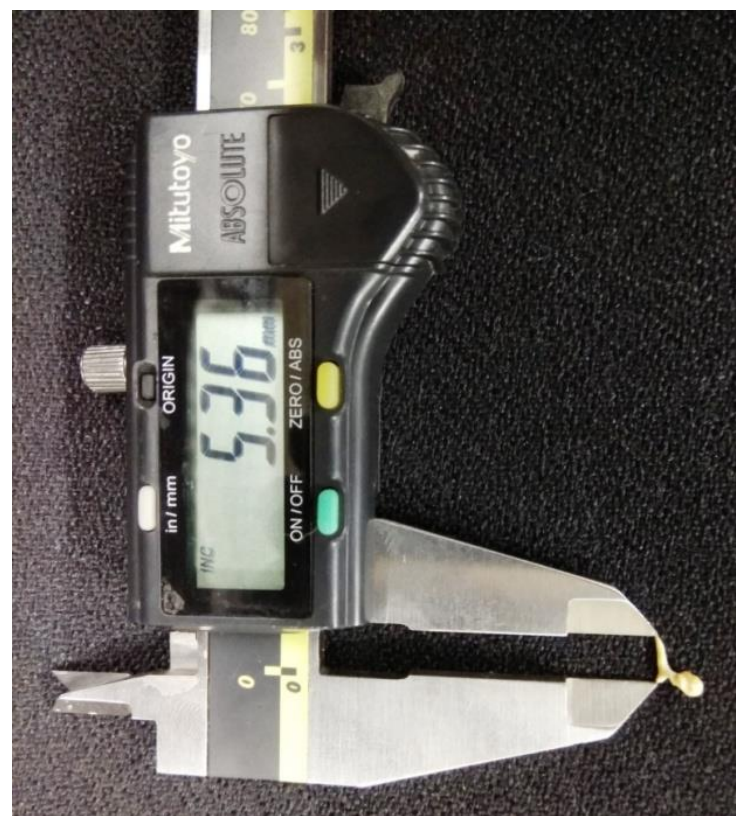

Fig. 2: Showing the measurement of length of manubrium of malleus

3. Length of head and neck of malleus [Fig. 3]

Length of head and neck of malleus was measured as the maximum straight distance between the top of the head and the end of the lateral process of the malleus.

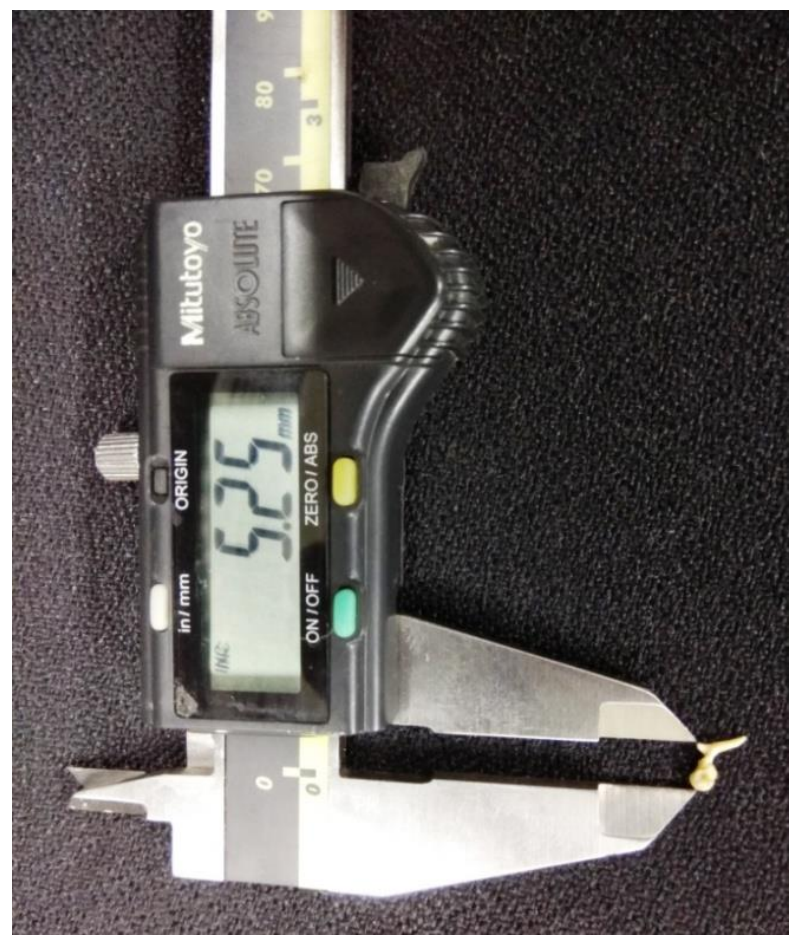

Fig. 3: Showing the measurement of length of head and neck of malleus

To avoid intra-observer variation, each measurement was taken at three different times and the mean of all three readings was taken as the final reading.

Above mentioned measurements were further used to calculate the following index:

1. Index of malleus

Index of malleus was calculated by using the following formula:

Index of malleus $=$ length of manubrium of malleus/ total length of malleus $x 100$

For each of this measurement, mean value, standard deviation, standard error of mean, range (minimummaximum), mean \pm SD (Standard Deviation) were calculated. Independent sample $t$ test was applied and $p$ value was calculated at $95 \%$ confidence interval by using SPSS (Statistical Package for the Social Sciences) software for the comparison of various parameters and index of malleus in male and female. 


\section{Results and Discussion}

Table 1: Showing the parameters, Sex-Male/Female, N-number of bones taken, Mean, SD-Standard deviation, Standard error of mean, Range (minimum-maximum), Mean \pm SD of various measurements and index of malleus

\begin{tabular}{|c|c|c|c|c|c|c|c|}
\hline Parameters & Sex & $\mathbf{N}$ & Mean & SD & $\begin{array}{c}\text { Std. Error } \\
\text { Mean }\end{array}$ & $\begin{array}{c}\text { Range } \\
(\text { min-max) }\end{array}$ & Mean \pm SD \\
\hline \multirow{2}{*}{$\begin{array}{l}\text { Total length of } \\
\text { malleus }\end{array}$} & male & 30 & $7.8847 \mathrm{~mm}$ & $0.4451 \mathrm{~mm}$ & $0.0813 \mathrm{~mm}$ & $\begin{array}{l}6.97 \mathrm{~mm} \mathrm{-} \\
8.70 \mathrm{~mm}\end{array}$ & $\begin{array}{c}7.4396 \mathrm{~mm}- \\
8.3298 \mathrm{~mm}\end{array}$ \\
\hline & female & 30 & $7.6280 \mathrm{~mm}$ & $0.4801 \mathrm{~mm}$ & $0.0877 \mathrm{~mm}$ & $\begin{array}{c}6.88 \mathrm{~mm} \mathrm{-} \\
8.38 \mathrm{~mm}\end{array}$ & $\begin{array}{c}7.1479 \mathrm{~mm}- \\
8.1081 \mathrm{~mm} \\
\end{array}$ \\
\hline \multirow{2}{*}{$\begin{array}{l}\text { Length of } \\
\text { manubrium of } \\
\text { malleus }\end{array}$} & male & 30 & $4.5943 \mathrm{~mm}$ & $0.4514 \mathrm{~mm}$ & $0.0824 \mathrm{~mm}$ & $\begin{array}{c}3.96 \mathrm{~mm}- \\
5.94 \mathrm{~mm}\end{array}$ & $\begin{array}{c}.1429 \mathrm{~mm} \mathrm{-} \\
5.0457 \mathrm{~mm} \\
\end{array}$ \\
\hline & female & 30 & $4.4787 \mathrm{~mm}$ & $0.3667 \mathrm{~mm}$ & $0.0669 \mathrm{~mm}$ & $\begin{array}{c}3.56 \mathrm{~mm} \mathrm{-} \\
5.12 \mathrm{~mm}\end{array}$ & $\begin{array}{c}4.1120 \mathrm{~mm}- \\
4.8454 \mathrm{~mm} \\
\end{array}$ \\
\hline \multirow{2}{*}{$\begin{array}{l}\text { Length of head } \\
\text { and neck of } \\
\text { malleus }\end{array}$} & male & 30 & $5.0627 \mathrm{~mm}$ & $0.3830 \mathrm{~mm}$ & $0.0699 \mathrm{~mm}$ & $\begin{array}{c}4.16 \mathrm{~mm} \mathrm{-} \\
5.65 \mathrm{~mm}\end{array}$ & $\begin{array}{c}4.6797 \mathrm{~mm} \mathrm{-} \\
5.4457 \mathrm{~mm} \\
\end{array}$ \\
\hline & female & 30 & $4.9490 \mathrm{~mm}$ & $0.2489 \mathrm{~mm}$ & $0.0454 \mathrm{~mm}$ & $\begin{array}{c}4.43 \mathrm{~mm} \mathrm{-} \\
5.50 \mathrm{~mm}\end{array}$ & $\begin{array}{c}4.7001 \mathrm{~mm} \mathrm{-} \\
5.1979 \mathrm{~mm}\end{array}$ \\
\hline \multirow[t]{2}{*}{$\begin{array}{l}\text { Index of } \\
\text { malleus }\end{array}$} & male & 30 & 58.2517 & 4.3775 & 0.7992 & $51.62-71.83$ & $\begin{array}{c}53.8742- \\
62.6292 \\
\end{array}$ \\
\hline & female & 30 & 58.7860 & 4.4245 & 0.8078 & $51.00-69.96$ & $54.3615-63.2105$ \\
\hline
\end{tabular}

As shown in the table 1 , in the present study, mean of total length of malleus in male is $7.8847 \mathrm{~mm}$, SD is 0.4451 $\mathrm{mm}$, range from $6.97 \mathrm{~mm}$ to $8.70 \mathrm{~mm}$ and mean \pm SD from $7.4396 \mathrm{~mm}$ to $8.3298 \mathrm{~mm}$. Mean of total length of malleus in female is $7.6280 \mathrm{~mm}, \mathrm{SD}$ is $0.4801 \mathrm{~mm}$, range from 6.88 $\mathrm{mm}$ to $8.38 \mathrm{~mm}$ and mean \pm SD from $7.1479 \mathrm{~mm}$ to 8.1081 $\mathrm{mm}$.

Mean of length of manubrium of malleus in male is $4.5943 \mathrm{~mm}, \mathrm{SD}$ is $0.4514 \mathrm{~mm}$, range from $3.96 \mathrm{~mm}$ to 5.94 $\mathrm{mm}$ and mean \pm SD from $4.1429 \mathrm{~mm}$ to $5.0457 \mathrm{~mm}$. Mean of length of manubrium of malleus in female is $4.4787 \mathrm{~mm}$, SD is $0.3667 \mathrm{~mm}$, range from $3.56 \mathrm{~mm}$ to $5.12 \mathrm{~mm}$ and mean \pm SD from $4.1120 \mathrm{~mm}$ to $4.8454 \mathrm{~mm}$.

Mean of length of head and neck of malleus in male is $5.0627 \mathrm{~mm}, \mathrm{SD}$ is $0.3830 \mathrm{~mm}$, range from $4.16 \mathrm{~mm}$ to 5.65 $\mathrm{mm}$ and mean \pm SD from $4.6797 \mathrm{~mm}$ to $5.4457 \mathrm{~mm}$. Mean of length of head and neck of malleus in female is $4.9490 \mathrm{~mm}$, SD is $0.2489 \mathrm{~mm}$, range from $4.43 \mathrm{~mm}$ to $5.50 \mathrm{~mm}$ and mean \pm SD from $4.7001 \mathrm{~mm}$ to $5.1979 \mathrm{~mm}$.

Mean of index of malleus in male is 58.2517 , SD is 4.3775 , range from 51.62 to 71.83 and mean \pm SD from 53.8742 to 62.6292 . Mean of index of malleus in female is $58.7860, \mathrm{SD}$ is 4.4245 , range from 51 to 69.96 and mean \pm SD from 54.3615 to 63.2105 .

Mean of total length of malleus, mean of length of manubrium of malleus and mean of length of head and neck of malleus in male are more as compared to female in the present study. Mean of index of malleus in male is less as compared to female in the present study.

Table 2: Showing the statistical analysis and the results of independent samples test applied to various measurements and index of malleus

\begin{tabular}{|c|c|c|c|c|c|c|c|c|c|c|}
\hline \multicolumn{11}{|c|}{ Independent Samples Test } \\
\hline & & \multicolumn{2}{|c|}{\begin{tabular}{|c|} 
Levene's Test for \\
Equality of \\
Variances
\end{tabular}} & \multicolumn{7}{|c|}{ t-test for Equality of Means } \\
\hline & & \multirow[t]{2}{*}{$\mathbf{F}$} & \multirow[t]{2}{*}{ Sig. } & \multirow[t]{2}{*}{$\mathbf{t}$} & \multirow[t]{2}{*}{ df } & \multirow[t]{2}{*}{$\begin{array}{l}\text { Sig. (2- } \\
\text { tailed) }\end{array}$} & \multirow[t]{2}{*}{$\begin{array}{c}\text { Mean } \\
\text { Difference }\end{array}$} & \multirow[t]{2}{*}{\begin{tabular}{|l|} 
Std. Error \\
Difference
\end{tabular}} & \multicolumn{2}{|c|}{$\begin{array}{l}\text { 95\% Confidence } \\
\text { Interval of the } \\
\text { Difference }\end{array}$} \\
\hline & & & & & & & & & Lower & Upper \\
\hline \multirow{2}{*}{$\begin{array}{l}\text { Total length of } \\
\text { malleus }\end{array}$} & $\begin{array}{l}\text { Equal variances } \\
\text { assumed }\end{array}$ & 1.307 & .258 & 2.147 & 58 & .036 & .2566667 & .1195318 & .0173978 & .4959355 \\
\hline & $\begin{array}{l}\text { Equal variances } \\
\text { not assumed }\end{array}$ & & & 2.147 & 57.670 & .036 & .2566667 & .1195318 & .0173687 & .4959647 \\
\hline \multirow{2}{*}{$\begin{array}{l}\text { Length of } \\
\text { manubrium of } \\
\text { malleus }\end{array}$} & $\begin{array}{l}\text { Equal variances } \\
\text { assumed }\end{array}$ & .288 & .594 & 1.089 & 58 & .281 & .1156667 & .1061797 & -.0968750 & .3282083 \\
\hline & $\begin{array}{l}\text { Equal variances } \\
\text { not assumed }\end{array}$ & & & 1.089 & 55.663 & .281 & .1156667 & .1061797 & -.0970652 & .3283985 \\
\hline
\end{tabular}




\begin{tabular}{|c|c|c|c|c|c|c|c|c|c|c|}
\hline \multirow{2}{*}{$\begin{array}{l}\text { Length of head } \\
\text { and neck of } \\
\text { malleus }\end{array}$} & $\begin{array}{l}\text { Equal variances } \\
\text { assumed }\end{array}$ & 5.480 & .023 & 1.363 & 58 & .178 & .1136667 & .0833870 & -.0532506 & .2805840 \\
\hline & $\begin{array}{l}\text { Equal variances } \\
\text { not assumed }\end{array}$ & & & 1.363 & 49.790 & .179 & .1136667 & .0833870 & -.0538386 & .2811720 \\
\hline \multirow{2}{*}{$\begin{array}{l}\text { Index of } \\
\text { malleus }\end{array}$} & $\begin{array}{l}\text { Equal variances } \\
\text { assumed }\end{array}$ & .067 & .797 & -.470 & 58 & .640 & -.5342799 & 1.1362460 & $\begin{array}{c}- \\
2.8087234 \\
\end{array}$ & 1.7401637 \\
\hline & $\begin{array}{l}\text { Equal variances } \\
\text { not assumed }\end{array}$ & & & -.470 & 57.994 & .640 & -.5342799 & 1.1362460 & $\begin{array}{c}- \\
2.8087288 \\
\end{array}$ & 1.7401690 \\
\hline
\end{tabular}

As shown in table 2, $\mathrm{p}$ value for the total length of malleus (for both- with equal variances assumed as well as equal variances not assumed) is 0.036 , which suggest statistically significant difference between the male and female malleus for the total length of malleus. $\mathrm{P}$ values for other parameters are more than 0.05 , which suggest that there is no statistically significant difference for these parameters of malleus between male and female.

Graph 1: Showing the distribution of observations of total length of malleus in male and female (with $95 \%$ confidence interval for mean) as well as line joining the mean of total length of malleus in male and mean of total length of malleus in female

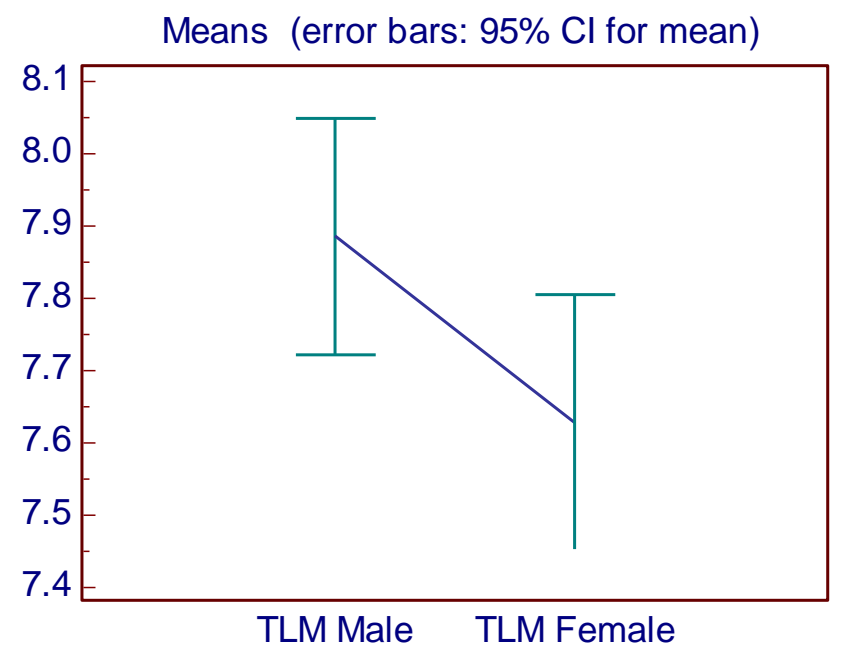

\section{(TLM: Total Length of Malleus)}

Graph 2: Showing the distribution of observations of length of manubrium of malleus in male and female (with $95 \%$ confidence interval for mean) as well as line joining the mean of length of manubrium of malleus in male and mean of length of manubrium of malleus in female

Means (error bars: $95 \% \mathrm{Cl}$ for mean)

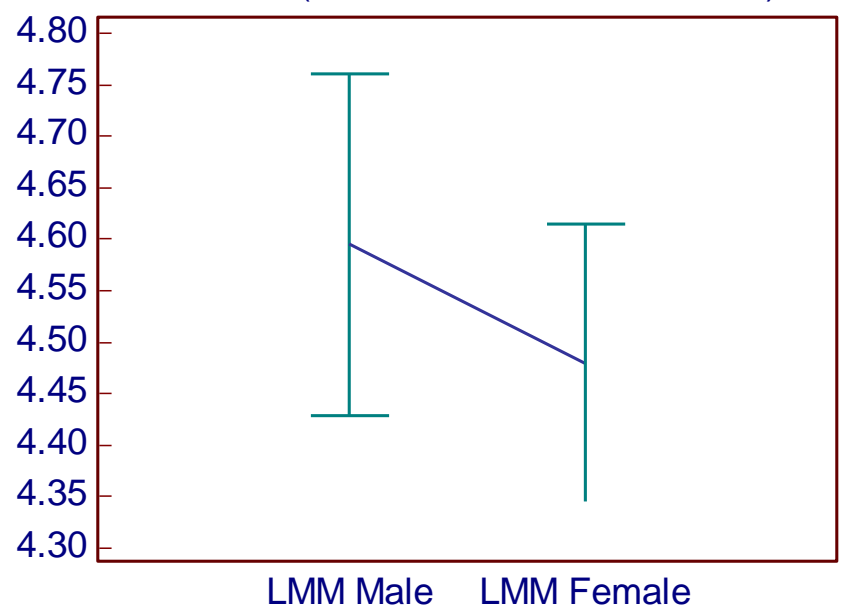

(LMM: Length of Manubrium of Malleus) 
Graph 3: Showing the distribution of observations of length of head and neck of malleus in male and female (with 95\% confidence interval for mean) as well as line joining the mean of length of head and neck of malleus in male and mean of length of head and neck of malleus in female.

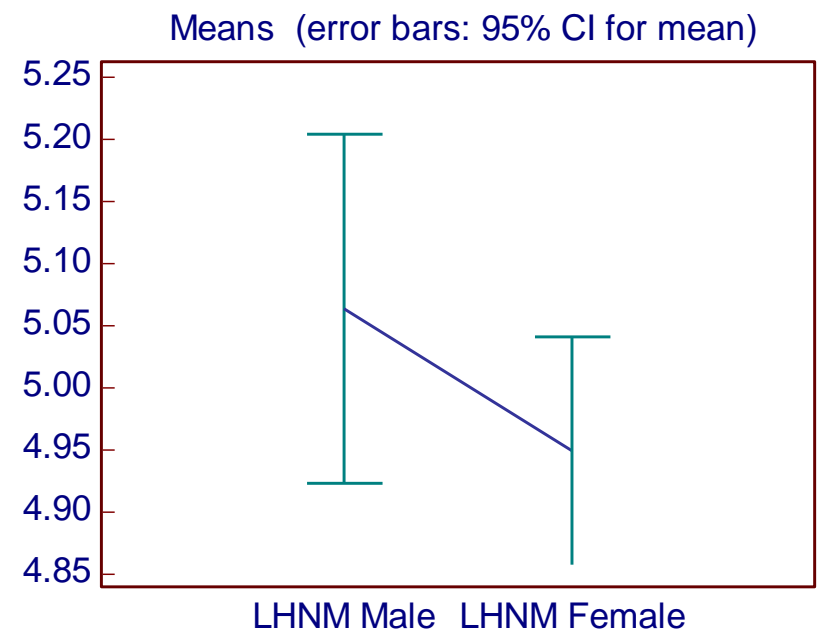

(LHNM: Length of Head and Neck of Malleus)

Graph 4: Showing the distribution of observations of index of malleus in male and female (with $95 \%$ confidence interval for mean) as well as line joining the mean of index of malleus in male and mean of index of malleus in female.

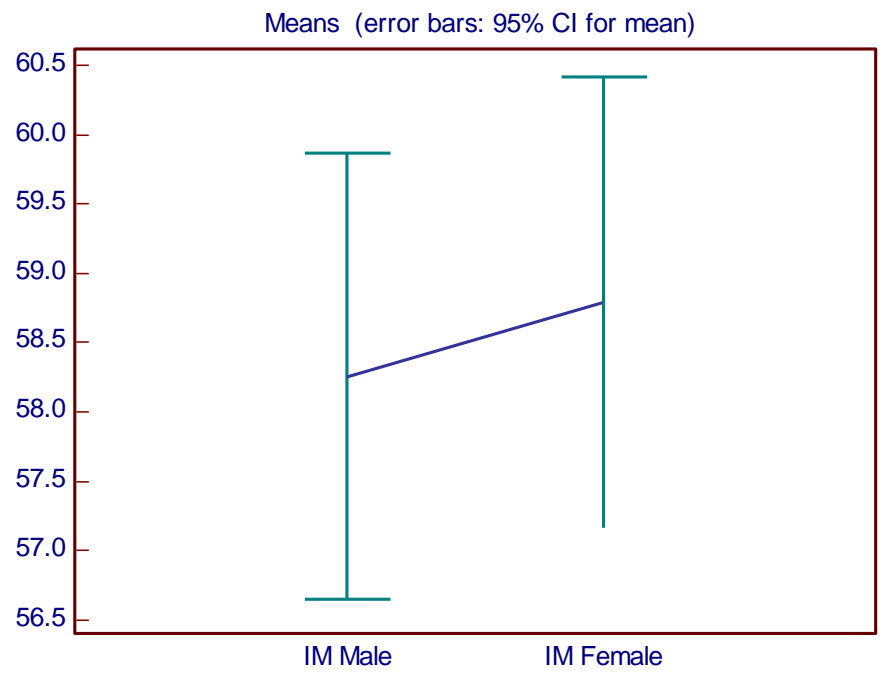

(IM: Index of Malleus)

Table 3: Showing the comparison of findings of various parameters and index of malleus of male and female in the present study with the findings of other researchers

\begin{tabular}{|c|c|c|c|c|c|c|c|c|}
\hline \multirow[b]{2}{*}{ No } & \multirow[b]{2}{*}{ Researcher } & \multirow[b]{2}{*}{$\begin{array}{c}\text { Study } \\
\text { population }\end{array}$} & \multirow[b]{2}{*}{$\begin{array}{c}\text { Sample } \\
\text { size }\end{array}$} & \multirow[b]{2}{*}{$\begin{array}{l}\text { Sex } \\
\text { and } \\
\text { side }\end{array}$} & \multicolumn{4}{|c|}{ Parameters } \\
\hline & & & & & $\begin{array}{c}\text { Total length } \\
\text { of malleus } \\
(\mathbf{m m}) \\
(\text { mean } \pm \text { SD })\end{array}$ & $\begin{array}{c}\text { Length of } \\
\text { manubrium } \\
\text { of malleus } \\
(\mathbf{m m}) \\
(\text { mean } \pm \text { SD })\end{array}$ & $\begin{array}{c}\text { Length of } \\
\text { head and } \\
\text { neck of } \\
\text { malleus } \\
(\mathrm{mm}) \\
(\text { mean } \pm \text { SD })\end{array}$ & $\begin{array}{c}\text { Index of } \\
\text { malleus } \\
(\text { mean } \pm S \\
\text { D) }\end{array}$ \\
\hline 1 & $\begin{array}{c}\text { Harneja NK } \\
\text { and Chaturvedi } \\
\text { RP } \\
(1973)\end{array}$ & $\begin{array}{l}\text { Rajasthan } \\
\text { India }\end{array}$ & 50 & - & $\begin{array}{c}7.15 \\
\pm 0.31\end{array}$ & $\begin{array}{c}4.22 \\
\pm 0.35\end{array}$ & 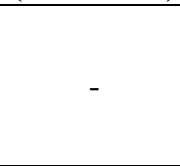 & - \\
\hline
\end{tabular}




\begin{tabular}{|c|c|c|c|c|c|c|c|c|}
\hline 2 & $\begin{array}{c}\text { Arensburg et al } \\
(1981)\end{array}$ & Indian & 31 & - & $\begin{array}{c}7.8 \\
\pm 0.35\end{array}$ & $\begin{array}{c}4.4 \\
\pm 0.47\end{array}$ & - & 56.6 \\
\hline 3 & $\begin{array}{c}\text { Oschman Z } \\
\text { and Meiring JH } \\
\text { (1991) }\end{array}$ & $\begin{array}{l}\text { South } \\
\text { african }\end{array}$ & 122 & - & 7.844 & 4.399 & - & - \\
\hline 4 & $\begin{array}{c}\text { Bhatnagar } \\
\text { DP et al } \\
(2001)\end{array}$ & $\begin{array}{c}\text { Patiala, } \\
\text { Punjab, } \\
\text { India }\end{array}$ & 60 & - & $\begin{array}{c}8.36 \\
\pm 1.39\end{array}$ & $\begin{array}{l}4.65 \\
\pm 0.27\end{array}$ & - & - \\
\hline 5 & $\begin{array}{c}\text { Unur E et al } \\
(2002)\end{array}$ & $\begin{array}{c}\text { Turkey } \\
\text { (newborn) }\end{array}$ & 40 & - & $\begin{array}{l}7.69 \\
\pm 0.6 \\
\end{array}$ & $\begin{array}{c}4.7 \\
\pm 0.45 \\
\end{array}$ & $\begin{array}{c}4.85 \\
\pm 0.29 \\
\end{array}$ & $\begin{array}{l}60.97 \\
\pm 3.77 \\
\end{array}$ \\
\hline \multirow{5}{*}{6} & \multirow{6}{*}{$\begin{array}{l}\text { Singh K et al } \\
\text { (2012) }\end{array}$} & \multirow{6}{*}{$\begin{array}{l}\text { Haryana } \\
\text { India }\end{array}$} & 60 & Right & $\begin{array}{c}7.947 \\
\pm 0.415\end{array}$ & $\begin{array}{c}4.762 \\
\pm 0.45139\end{array}$ & $\begin{array}{c}5.237 \\
\pm 0.3409\end{array}$ & - \\
\hline & & & 60 & Left & $\begin{array}{l}7.9467 \\
\pm 0.401\end{array}$ & $\begin{array}{c}4.726 \\
\pm 0.376\end{array}$ & $\begin{array}{c}5.2172 \\
\pm 0.4\end{array}$ & - \\
\hline & & & 30 & $\begin{array}{l}\text { Male } \\
\text { right }\end{array}$ & $\begin{array}{c}8.078 \\
\pm 0.453\end{array}$ & $\begin{array}{c}4.896 \\
\pm 0.384\end{array}$ & $\begin{array}{c}5.194 \\
\pm 0.363\end{array}$ & - \\
\hline & & & 30 & $\begin{array}{c}\text { Female } \\
\text { right }\end{array}$ & $\begin{array}{c}7.817 \\
\pm 0.334 \\
\end{array}$ & $\begin{array}{l}4.628 \\
\pm 0.48 \\
\end{array}$ & $\begin{array}{c}5.28 \\
\pm 0.318 \\
\end{array}$ & - \\
\hline & & & 30 & $\begin{array}{c}\text { Male } \\
\text { left }\end{array}$ & $\begin{array}{c}8.045 \\
\pm 0.471 \\
\end{array}$ & $\begin{array}{c}4.844 \\
\pm 0.341 \\
\end{array}$ & $\begin{array}{c}5.21 \\
\pm 0.462 \\
\end{array}$ & - \\
\hline & & & 30 & $\begin{array}{c}\text { Female } \\
\text { left }\end{array}$ & $\begin{array}{c}7.848 \\
\pm 0.294 \\
\end{array}$ & $\begin{array}{c}4.608 \\
\pm 0.379 \\
\end{array}$ & $\begin{array}{c}5.224 \\
\pm 0.335 \\
\end{array}$ & - \\
\hline 7 & $\begin{array}{c}\text { Nadeem G } \\
(2012-13)\end{array}$ & Indian & 30 & - & $\begin{array}{c}8 \\
\pm 0.046 \\
\end{array}$ & $\begin{array}{c}4.58 \\
\pm 0.015 \\
\end{array}$ & & \\
\hline 8 & $\begin{array}{c}\text { Ramirez LM } \\
\text { and Ballesteros } \\
\text { LE } \\
(2013)\end{array}$ & Columbian & 23 & - & $\begin{array}{c}8.18 \\
\pm 0.24\end{array}$ & $\begin{array}{c}4.91 \\
\pm 0.25\end{array}$ & - & - \\
\hline \multirow{3}{*}{9} & \multirow{3}{*}{$\begin{array}{l}\text { Mogra K et al } \\
\text { (2014) }\end{array}$} & \multirow{3}{*}{$\begin{array}{l}\text { Rajasthan } \\
\text { India }\end{array}$} & 66 & Total & $\begin{array}{c}8.53 \\
\pm 0.58\end{array}$ & $\begin{array}{c}5.2 \\
\pm 0.48\end{array}$ & $\begin{array}{c}4.72 \\
\pm 0.82\end{array}$ & $\begin{array}{l}61.01 \\
\pm 3.74\end{array}$ \\
\hline & & & 33 & Right & $\begin{array}{c}8.515 \\
\pm 0.6553\end{array}$ & $\begin{array}{c}5.106 \\
\pm 0.4636\end{array}$ & $\begin{array}{c}4.606 \\
\pm 0.8078\end{array}$ & $\begin{array}{r}60.18 \\
\pm 3.555 \\
\end{array}$ \\
\hline & & & 33 & Left & $\begin{array}{c}8.545 \\
\pm 0.5056 \\
\end{array}$ & $\begin{array}{c}5.303 \\
\pm 0.4831 \\
\end{array}$ & $\begin{array}{c}4.833 \\
\pm 0.826 \\
\end{array}$ & $\begin{array}{c}61.84 \\
\pm 3.788 \\
\end{array}$ \\
\hline 10 & $\begin{array}{l}\text { Vinayachandra } \\
\text { PH et al (2014) }\end{array}$ & $\begin{array}{l}\text { South } \\
\text { Indian }\end{array}$ & 50 & - & $\begin{array}{c}7.45 \\
\pm 0.39\end{array}$ & - & - & - \\
\hline 11 & $\begin{array}{c}\text { Rathava J et al } \\
(2015)\end{array}$ & Gujarati & 60 & - & $\begin{array}{c}7.81 \\
\pm 0.32 \\
\end{array}$ & $\begin{array}{c}4.59 \\
\pm 0.34 \\
\end{array}$ & $\begin{array}{c}5 \\
\pm 0.2 \\
\end{array}$ & - \\
\hline 12 & $\begin{array}{c}\text { K Radha } \\
(2016)\end{array}$ & $\begin{array}{l}\text { South } \\
\text { Indian }\end{array}$ & 25 & - & 7.4 & 4.2 & - & - \\
\hline \multirow{3}{*}{13} & \multirow{3}{*}{$\begin{array}{l}\text { Sodhi S et al } \\
\quad(2017)\end{array}$} & \multirow{3}{*}{$\begin{array}{l}\text { North } \\
\text { India }\end{array}$} & 100 & Total & 7.83 & 4.44 & 4.68 & 56.77 \\
\hline & & & 50 & Right & $\begin{array}{c}7.87 \\
\pm 0.37 \\
\end{array}$ & $\begin{array}{c}4.47 \\
\pm 0.41 \\
\end{array}$ & $\begin{array}{c}4.7 \\
\pm 0.43 \\
\end{array}$ & 56.77 \\
\hline & & & 50 & Left & $\begin{array}{c}7.8 \\
\pm 0.54 \\
\end{array}$ & $\begin{array}{c}4.42 \\
\pm 0.42 \\
\end{array}$ & $\begin{array}{c}4.68 \\
\pm 0.41 \\
\end{array}$ & 56.78 \\
\hline \multirow{2}{*}{14} & \multirow{2}{*}{$\begin{array}{l}\text { Present study } \\
\quad(2017-18)\end{array}$} & \multirow{2}{*}{$\begin{array}{l}\text { Kachchhi } \\
\text { (Gujarati) }\end{array}$} & 30 & Male & $\begin{array}{c}7.8847 \\
\pm 0.4451 \\
\end{array}$ & $\begin{array}{c}4.5943 \\
\pm 0.4514 \\
\end{array}$ & $\begin{array}{l}5.0627 \\
\pm 0.383 \\
\end{array}$ & $\begin{array}{l}58.2517 \\
\pm 4.3775 \\
\end{array}$ \\
\hline & & & 30 & Female & $\begin{array}{c}7.628 \\
\pm 0.4801 \\
\end{array}$ & $\begin{array}{c}4.4787 \\
\pm 0.3667\end{array}$ & $\begin{array}{c}4.949 \\
\pm 0.2489 \\
\end{array}$ & $\begin{array}{c}58.786 \\
\pm 4.4245\end{array}$ \\
\hline
\end{tabular}

As shown in table 3, Harneja NK and Chaturvedi RP in 1973 measured the total length and length of manubrium of malleus in Rajasthani population (sample size 50). In that study, mean of total length of malleus was $7.15 \mathrm{~mm}$ with SD $0.31 \mathrm{~mm}$ and mean of length of manubrium of malleus was $4.22 \mathrm{~mm}$ with SD $0.35 \mathrm{~mm}$.
Arensburg et al in 1981 measured the total length, length of manubrium and index of malleus in Indian population (sample size 31). In that study, mean of total length of malleus was $7.8 \mathrm{~mm}$ with SD $0.35 \mathrm{~mm}$, mean of length of manubrium of malleus was $4.4 \mathrm{~mm}$ with SD 0.47 $\mathrm{mm}$ and mean of index of malleus was 56.6. 
Oschman Z and Meiring JH in 1991 measured the total length and length of manubrium of malleus in South African population (sample size 122). In that study, mean of total length of malleus was $7.844 \mathrm{~mm}$ and mean of length of manubrium of malleus was 4.399 .

Bhatnagar DP et al in 2001 measured the total length and length of manubrium of malleus in population of Patiala (Punjab, India) (sample size 60). In that study, mean of total length of malleus was $8.36 \mathrm{~mm}$ with SD $1.39 \mathrm{~mm}$ and mean of length of manubrium of malleus was $4.65 \mathrm{~mm}$ with SD $0.27 \mathrm{~mm}$.

Unur E et al in 2002 measured the total length, length of manubrium, length of head and neck and index of malleus in Turkish population (sample size 40). In that study, mean of total length of malleus was $7.69 \mathrm{~mm}$ with SD $0.6 \mathrm{~mm}$, mean of length of manubrium of malleus was $4.7 \mathrm{~mm}$ with SD $0.45 \mathrm{~mm}$, mean of length of head and neck of malleus was $4.85 \mathrm{~mm}$ with SD $0.29 \mathrm{~mm}$ and mean of index of malleus was 60.97 with SD 3.77.

Singh K et al in 2012 measured the total length, length of manubrium and length of head and neck of malleus in population of Haryana, India (sample size: male right 30, male left 30 , female right 30 , female left 30 ). In that study, mean of total length of malleus of right side was $7.947 \mathrm{~mm}$ with SD $0.415 \mathrm{~mm}$, of left side was $7.9467 \mathrm{~mm}$ with SD $0.401 \mathrm{~mm}$, of male right side was $8.078 \mathrm{~mm}$ with SD 0.453 $\mathrm{mm}$, of female right side was $7.817 \mathrm{~mm}$ with SD $0.334 \mathrm{~mm}$, of male left side was $8.045 \mathrm{~mm}$ with SD $0.471 \mathrm{~mm}$ and of female left side was $7.848 \mathrm{~mm}$ with SD $0.294 \mathrm{~mm}$. In that study, mean of length of manubrium of malleus of right side was $4.762 \mathrm{~mm}$ with SD $0.45139 \mathrm{~mm}$, of left side was 4.726 $\mathrm{mm}$ with SD $0.376 \mathrm{~mm}$, of male right side was $4.896 \mathrm{~mm}$ with SD $0.384 \mathrm{~mm}$, of female right side was $4.628 \mathrm{~mm}$ with SD $0.48 \mathrm{~mm}$, of male left side was $4.844 \mathrm{~mm}$ with SD 0.341 $\mathrm{mm}$ and of female left side was $4.608 \mathrm{~mm}$ with SD 0.379 $\mathrm{mm}$. In that study, mean of length of head and neck of malleus of right side was $5.237 \mathrm{~mm}$ with SD $0.3409 \mathrm{~mm}$, of left side was $5.2172 \mathrm{~mm}$ with SD $0.4 \mathrm{~mm}$, of male right side was $5.194 \mathrm{~mm}$ with SD $0.363 \mathrm{~mm}$, of female right side was $5.28 \mathrm{~mm}$ with SD $0.318 \mathrm{~mm}$, of male left side was $5.21 \mathrm{~mm}$ with SD $0.462 \mathrm{~mm}$ and of female left side was $5.224 \mathrm{~mm}$ with SD $0.335 \mathrm{~mm}$.

Nadeem G in 2012-13 measured the total length and length of manubrium of malleus in Indian population (sample size 30). In that study, mean of total length of malleus was $8 \mathrm{~mm}$ with SD $0.046 \mathrm{~mm}$ and mean of length of manubrium of malleus was $4.58 \mathrm{~mm}$ with SD $0.015 \mathrm{~mm}$.

Ramirez LM and Ballesteros LE in 2013 measured the total length and length of manubrium of malleus in Columbian population (sample size 23). In that study, mean of total length of malleus was $8.18 \mathrm{~mm}$ with SD $0.24 \mathrm{~mm}$ and mean of length of manubrium of malleus was $4.91 \mathrm{~mm}$ with SD $0.25 \mathrm{~mm}$.

Mogra K et al in 2014 measured the total length, length of manubrium, length of head and neck and index of malleus in population of Rajasthan, India (sample size: right 33 , left 33). In that study, mean of total length of malleus was $8.53 \mathrm{~mm}$ with SD $0.58 \mathrm{~mm}$, of right side was $8.515 \mathrm{~mm}$ with SD $0.6553 \mathrm{~mm}$ and of left side was $8.545 \mathrm{~mm}$ with SD $0.5056 \mathrm{~mm}$. In that study, mean of length of manubrium of malleus was $5.2 \mathrm{~mm}$ with SD $0.48 \mathrm{~mm}$, of right side was $5.106 \mathrm{~mm}$ with SD $0.4636 \mathrm{~mm}$ and of left side was 5.303 $\mathrm{mm}$ with SD $0.4831 \mathrm{~mm}$. In that study, mean of length of head and neck of malleus was $4.72 \mathrm{~mm}$ with SD $0.82 \mathrm{~mm}$, of right side was $4.606 \mathrm{~mm}$ with SD $0.8078 \mathrm{~mm}$ and of left side was $4.833 \mathrm{~mm}$ with SD $0.826 \mathrm{~mm}$. In that study, mean of index of malleus was 61.01 with SD 3.74, of right side was 60.18 with SD 3.555 and of left side was 61.84 with SD 3.788 .

Vinayachandra PH et al in 2014 measured the total length of malleus in South Indian population (sample size 50). In that study, mean of total length of malleus was 7.45 $\mathrm{mm}$ with SD $0.39 \mathrm{~mm}$.

Rathava $\mathbf{J}$ et al in 2015 measured the total length, length of manubrium and length of head and neck of malleus in population of Gujarat, India (sample size 60). In that study, mean of total length of malleus was $7.81 \mathrm{~mm}$ with SD 0.32 $\mathrm{mm}$, mean of length of manubrium of malleus was $4.59 \mathrm{~mm}$ with SD $0.34 \mathrm{~mm}$ and mean of length of head and neck of malleus was $5 \mathrm{~mm}$ with SD $0.2 \mathrm{~mm}$.

K Radha in 2016 measured the total length and length of manubrium of malleus in South Indian population (sample size 25). In that study, mean of total length of malleus was $7.4 \mathrm{~mm}$ and mean of length of manubrium of malleus was $4.2 \mathrm{~mm}$.

Sodhi $\mathrm{S}$ et al in 2017 measured the total length, length of manubrium, length of head and neck and index of malleus in North Indian population (sample size: right 50, left 50). In that study, mean of total length of malleus was $7.83 \mathrm{~mm}$, of right side was $7.87 \mathrm{~mm}$ with SD $0.37 \mathrm{~mm}$ and of left side was $7.8 \mathrm{~mm}$ with SD $0.54 \mathrm{~mm}$. In that study, mean of length of manubrium of malleus was $4.44 \mathrm{~mm}$, of right side was $4.47 \mathrm{~mm}$ with SD $0.41 \mathrm{~mm}$ and of left side was $4.42 \mathrm{~mm}$ with SD $0.42 \mathrm{~mm}$. In that study, mean of length of head and neck of malleus was $4.68 \mathrm{~mm}$, of right side was $4.7 \mathrm{~mm}$ with SD $0.43 \mathrm{~mm}$ and of left side was 4.68 $\mathrm{mm}$ with SD $0.41 \mathrm{~mm}$. In that study, mean of index of malleus was 56.77, of right side was 56.77 and of left side was 56.78 .

In the present study (2017-18), we measured the total length, length of manubrium, length of head and neck and index of malleus in population of Kachchh, Gujarat, India. In this study, mean of total length of malleus in male is $7.8847 \mathrm{~mm}$ with SD 0.4451 and in female it is $7.628 \mathrm{~mm}$ with SD $0.4801 \mathrm{~mm}$. Mean of length of manubrium of malleus in male is $4.5943 \mathrm{~mm}$ with SD $0.4514 \mathrm{~mm}$ and in female it is $4.4787 \mathrm{~mm}$ with SD $0.3667 \mathrm{~mm}$. Mean of length of head and neck of malleus in male is $5.0627 \mathrm{~mm}$ with SD $0.383 \mathrm{~mm}$ and in female it is $4.949 \mathrm{~mm}$ with SD 0.2489 $\mathrm{mm}$. Mean of index of malleus in male is 58.2517 with SD 4.3775 and in female it is 58.786 with SD 4.4245 .

\section{Conclusion}

We determined the normal range of the values of various measurements and index of malleus in the Kachchhi Gujarati population of present study. Among all the 
measurements taken in the present study; total length of malleus having statistically significant difference between the male and female malleus and it can be used for the sexual dimorphism of malleus for Kachchhi Gujarati population of present study.

\section{Conflict of Interest: Nil.}

\section{References}

1. Standring S. Gray's anatomy 40th Edition. Anatomical Basis Of Clinical Practice, Churchill Livingstone, London 2008; $36: 627$

2. Harneja NK, Chaturvedi RP. A study of the human ear ossicles. Indian J Otol 1973;25:154-160.

3. Arensburg B, Harell M, Nathan H. The human middle ear ossicles, morphometry and taxonomic implications. J Hum Evol 1981;10:199-205.

4. Oschman $\mathrm{Z}$ and Meiring JH; A Morphometric and Comparative Study of The Malleus; Acta Anatomica 1991;142(1):60-61.

5. Bhatnagar DP, Singal P and Thapar SP; Anatomy of MalleusA Human Ear Ossicle; Anthropologists 2001;3(2):139-141.

6. Unur E, Ulger H, Ekinci N. Morphometrical and Morphological variations in the middle ear ossicles in the newborn. Erciyes Med J 2002;24(2):57-63.

7. Singh K, Chhabra S, Sirohiwal BL, Yadav SPS. Morphometry of malleus a possible tool in sex determination. J Forensic Res 2012;3(6):1-3.

8. Nadeem G. Can fetal ossicles be used as prosthesis in adults? A morphometric study. Int J Exp Clin Anat 2012-13;6(7):5257.
9. Ramirez, LM and Ballesteros, LE; Anthropometry of the Malleus in Humans: A Direct Anatomic Study; Int J Morphol 2013;31(1):177-183.

10. Mogra K, Gupta S, Chauhan S. Morphological and morphometrical variations of malleus in human cadavers. Int $J$ Healthc Biomed Res 2014;2(3):186-192.

11. Vinaychandra P H. Morphometry and variations of malleus with clinical correlation. Int J Anat Res 2014;2(1):191-194.

12. Rathava J, Trivedi P, Kukadiya U. Morphometric study of malleus in Gujarati population. Int J Adv Res 2015;3(3):306310.

13. Radha K. Morphological and morphometric study of malleus in South Indian population. Int J Anat Res 2016;4(2):23422344.

14. Sodhi S, Singh Z, Lal J. Morphometric dimensions of human ear ossicles of males. Natl J Med Res 2017;7(1):47-51.

How to cite this article: Javia $M$, Saravanan $P$. Morphometric analysis of various measurements of malleus on the basis of sexual dimorphism. Indian $J$ Anat Surg Head Neck Brain 2018;4(4):94-101. 